\title{
The Phenomenon of Online Learning in Educational Institutions during the COVID-19 Pandemic
}

\author{
Abdul Azis ${ }^{1,}{ }^{*}$, Mustiningsih ${ }^{1}$ \\ ${ }^{I}$ Department of Educational Administration, Faculty of Education, Universitas Negeri Malang, Malang, Indonesia \\ *Corresponding author.Email: s3abdulazis@gmail.com
}

\begin{abstract}
This study aims to determine the appropriate learning methods for teachers in remote areas during the COVID-19 pandemic. This research was conducted with a literature study method. Data collection techniques using literature studies. The results of this study conclude that the main problem of online learning is internet connection. In remote areas of Indonesia, online teaching and learning activities have not been carried out at all. This makes teachers have to make extra efforts with the rolling learning method (traveling teacher) who goes around to visit students' homes to teach, so that students in remote villages can still learn even though they are constrained by signals in online learning.
\end{abstract}

Keywords: learning methods, underdeveloped villages, internet network

\section{INTRODUCTION}

During Covid-19 pandemic has hit, almost all schools in Indonesia do online learning, in which the learning method which uses an interactive internet-based model and a Learning Management System (LMS). Like using the google meet application, zoom and other supporting applications [1], [2].

Online learning is a part of distance education that specifically combines electronic technology and internetbased technology [3], [4]. Students who do not have cell phones, even students who cannot afford internet quota [5], [6], are not one of the main problems anymore, but in fact the internet network is the main problem, especially for teachers who live in remote villages in underdeveloped regions [6], [7]. In underdeveloped villages, face-to-face teaching and learning activities have not yet been implemented in schools.

This makes teachers have to make extra efforts with the rolling learning method (traveling teachers) who visit students' homes to teach, online learning [8], [9]. This also happened in the Mentaya Hilir Selatan Regency, Indonesia. Apart from these areas, there are also many villages in Kotawaringin Timur Regency, Indonesia, also experiencing the same thing. There are 72 underdeveloped villages, which experience problems with online learning.

\section{METHOD}

This research was conducted using a literature study method. The data collection technique used a documentation study and was carried out from July to September 2020. Researchers examined articles, online news, and books that supported the data collection process [10], [11]. From these various sources, the researcher reduced and drew conclusions with reference to the research objectives.

\section{RESULT AND DISCUSSION}

Since Nadiem Makarim as a Minister of Education and Culture implemented learning from home at the end of March, this has shown the inequality of education in the Indonesian archipelago. Nadiem Anwar Makarim, the minister of education and culture published Circular Number 4 of 2020 concern to the implementation of education during pandemic (Covid-19).

One of the important points in this circular is the decision to cancel national exam in 2020. Regarding studying from home, the Minister of Education and Culture emphasizes that online / distance learning is carried out to provide meaningful learning experiences for students, without being burdened with demands to complete all curriculum achievements for class promotion and graduation.

Teachers in underdeveloped villages realized that their decision to teach students from house to house using the rolling learning method during Covid-19 pandemic was not in accordance with the government's appeal. However, they admit that they have no other choice regarding the real conditions faced by their students, and pressure from parents of students has also asked teachers to teach their children face-to-face. 
Therefore, learning never stops from the womb to the grave [12], [13], set aside a little of your time to study again so that in the future you will not be left out because of a lack of knowledge [14], [15].

\section{CONCLUSION}

Online learning activities during Covid-19 pandemic on average have not been effective. From the results of the research that there are still some who do not carry out online learning in the midst of the Covid-19 pandemic, the learning method used is still dominant in giving assignments to students.

Many teachers understanding gets stuck on interpretation that teaching and learning have meaning only in giving questions from the teacher to students and the teaching method. It definitely shows that our homework is excruciatingly hard for all of us to improve our education systems. Especially for teachers who are in the village (disadvantaged, foremost and outermost in Indonesia).

\section{REFERENCES}

[1] Saputra, B. R., Adha, M. A., Ariyanti, N. S., \& Gunawan, I. (2019, December). Tips for Principal in Managing One Roof School (SATAP) in Underdeveloped Area. In the 4th International Conference on Education and Management (COEMA 2019). Atlantis Press.

[2] Putri, A. A. F., Putri, A. F., Andriningrum, H., Rofiah, S. K., \& Gunawan, I. (2019, December). Teacher Function in Class: A Literature Review. In 5th International Conference on Education and Technology (ICET 2019). Atlantis Press

[3] Gunawan, I. (2019, December). Develop Educational Leadership by Applying Values and Ethics to Strengthen Student Character. In 5th International Conference on Education and Technology (ICET 2019). Atlantis Press.

[4] Bafadal, I. I., Bafadal, I., Sobri, A. Y., Nurabadi, A., \& Gunawan, I. (2019, December). Standards of Competency of Head of School Beginners as Leaders in Learning Innovation. In 5th International Conference on Education and Technology (ICET 2019). Atlantis Press.

[5] Nurabadi, A., Gunawan, I., \& Sari, Y. L. (2019, December). The Application of Informal Supervision to Improve the Quality of Learning in Laboratory Schools. In the 4th International Conference on Education and Management (COEMA 2019). Atlantis Press.

[6] Sobri, A. Y., Bafadal, I., Nurabadi, A., \& Gunawan, I. (2019, December). Validity and Reliability of Questionnaire Problematics Leadership Beginner School Principals. In the 4th International Conference on Education and Management (COEMA 2019). Atlantis Press.

[7] Sumarsono, R. B., Kusumaningrum, D. E., Gunawan, I., Alfarina, M., Romady, M., Ariyanti, N. S., \& Budiarti, E. M. (2019, December). Training on the Implementation of
Cooperative Learning Models as an Effort to Improve Teacher's Performance. In the 4th International Conference on Education and Management (COEMA 2019). Atlantis Press.

[8] Nurabadi, A. A., Nurabadi, A., Sucipto, S., \& Gunawan, I. (2019, December). Informal Supervision Model "Managing by Walking About" in Improving Quality of Learning. In 5th International Conference on Education and Technology (ICET 2019). Atlantis Press.

[9] Gunawan, I., Kusumaningrum, D. E., Triwiyanto, T., Zulkarnain, W., Nurabadi, A., Sanutra, M. F. A., ... \& Yuantika, E. A. F. (2018, October). Hidden Curriculum and Character Building on Self-Motivation based on Kmeans Clustering. In 2018 4th International Conference on Education and Technology (ICET) (pp. 32-35). IEEE.

[10] Gunawan, I. (2016). Pengaruh Kepemimpinan Transformasional dan Kepuasan Kerja terhadap Perilaku Kewargaan Organisasi Guru Sekolah Dasar Negeri Kecamatan Kras Kabupaten Kediri. Premiere Educandum: Jurnal Pendidikan Dasar dan Pembelajaran, $5(01)$

[11] Gunawan, I., Benty, D. D. N., Kusumaningrum, D. E., Sumarsono, R. B., Sari, D. N., Pratiwi, F. D., ... \& Hui, L. K. (2019). Validitas Dan Reliabilitas Angket Keterampilan Manajerial Mahasiswa. JAMP: Jurnal Administrasi dan Manajemen Pendidikan, 2(4), 247-257.

[12] Gunawan, I., Benty, D. D. N., Kusumaningrum, D. E., Sumarsono, R. B., Sari, D. N., Pratiwi, F. D., ... \& Hui, L. K. (2020). Pengaruh Gaya Kepemimpinan, Kemampuan Manajerial, Efikasi Diri, Dan Prestasi Belajar Terhadap Kesiapan Kerja Mahasiswa. JMSP (Jurnal Manajemen dan Supervisi Pendidikan), 4(2), 126-150.

[13] Kusumaningrum, D. D. E., Ulfatin, N. N., Maisyaroh, M., Triwiyanto, T. T., \& Gunawan, I. I. (2017, August). Community Participation in Improving Educational Quality. In 2nd International Conference on Educational Management and Administration (CoEMA 2017). Atlantis Press.

[14] Sukawati, N. N., Gunawan, I., Ubaidillah, E., Maulina, S., \& Santoso, F. B. (2020, November). Human Resources Management in Basic Education Schools. In 2nd Early Childhood and Primary Childhood Education (ECPE 2020) (pp. 292-299). Atlantis Press.

[15] Tryanasari, D., Mursidik, E. M., \& Gunawan, I. (2013). Pengembangan Buku Pedoman Microteaching Berbasis Lesson Study Prodi PGSD FIP IKIP PGRI MADIUN. Jurnal Pendidikan, 19(1)

[16] Gunawan, I., Kusumaningrum, D. E., Triwiyanto, T., Zulkarnain, W., \& Nurabadi, A. (2018, October). Pengaruh Kurikulum Tersembunyi terhadap Motivasi Diri Mahasiswa. In Prosiding Seminar Nasional Pendidikan, Tema: Mendidik Cerdas Generasi Digital, Fakultas Ilmu Pendidikan Universitas Negeri Malang, Malang (Vol. 4, pp. 90-97).

[17] Kurniawati, R. P., Gunawan, I., \& Marlina, D. (2020, November). Mathematic Literation Abilities Based on Problem Solving Abilities in First Class 4 of Elementary 
School. In 2nd Early Childhood and Primary Childhood Education (ECPE 2020) (pp. 186-192). Atlantis Press.

[18] Gunawan, I., Bafadal, I., Nurabadi, A., \& Prayoga, A. G. (2020, November). Identification of Themes in the Moral Debate Program as an Effort to Increase Work Integrity of Principal. In 2nd Early Childhood and Primary Childhood Education (ECPE 2020) (pp. 24-28). Atlantis Press.

[19] Imron, A., Wiyono, B. B., Hadi, S., Gunawan, I., Abbas, A., Saputra, B. R., \& Perdana, D. B. (2020, November). Teacher Professional Development to Increase Teacher Commitment in the Era of the Asean Economic Community. In 2nd Early Childhood and Primary Childhood Education (ECPE 2020) (pp. 339-343). Atlantis Press.

[20] Sultoni, S., Gunawan, I., \& Pratiwi, F. D. (2018). Perbedaan Motivasi Belajar Mahasiswa antara Sebelum dan Sesudah Mengikuti Pelatihan Motivasional. Ilmu Pendidikan: Jurnal Kajian Teori dan Praktik Kependidikan, 3(1), 115-119.

[21] Gunawan, I., Alifiyah, I., \& Evananda, F. (2017, November). Kompetensi Guru Sekolah Dasar: Sebuah Analisis Reflektif dengan Teknik Supervisi Pengajaran Penilaian Diri Sendiri. In Prosiding Seminar Nasional Sinergitas Keluarga, Sekolah, dan Masyarakat dalam Penguatan Pendidikan Karakter. Fakultas Ilmu
Pendidikan Universitas Negeri Malang, Malang (Vol. 16, pp. 249-258).

[22] Bafadal, I., Nurabadi, A., Soepriyanto, Y., \& Gunawan, I. (2020, November). Primary School Principal Performance Measurement. In 2nd Early Childhood and Primary Childhood Education (ECPE 2020) (pp. 19-23). Atlantis Press.

[23] Gunawan, I., Triwiyanto, T., Kusumaningrum, D. E., Romady, M., Alfarina, M., \& Widiana, R. A. (2018). Pemberdayaan Tenaga Administrasi Sekolah Menengah Pertama Kota Batu: Studi Deskriptif. JAMP: Jurnal Administrasi dan Manajemen Pendidikan, 1(4), 467-471.

[24] Wardani, A. D., Gunawan, I., Kusumaningrum, D. E., Benty, D. D. N., Sumarsono, R. B., Nurabadi, A., \& Handayani, L. (2020, November). Student Learning Motivation: A Conceptual Paper. In 2nd Early Childhood and Primary Childhood Education (ECPE 2020) (pp. 275278). Atlantis Press.

[25] Zahro, Z. R., Andriningrum, H., Sari, E. P., \& Gunawan, I. (2017, November). Sekolah Siaga Bencana: Kajian Evaluatif Kesiapsiagaan Sekolah Menghadapi Bencana. In Seminar Nasional Pendidikan Sinergitas Keluarga, Sekolah, dan Masyarakat dalam Penguatan Pendidikan Karakter, Fakultas Ilmu Pendidikan Universitas Negeri Malang, Malang, Indonesia (pp. 249-258). 